\title{
Arabian Red Sea coastal soils as potential mineral dust sources
}

\author{
P. Jish Prakash ${ }^{1}$, Georgiy Stenchikov ${ }^{1}$, Weichun Tao ${ }^{1}$, Tahir Yapici ${ }^{1}$, Bashir Warsama ${ }^{1}$, and Johann P. Engelbrecht ${ }^{1,2}$ \\ ${ }^{1}$ King Abdullah University of Science and Technology (KAUST), Physical Science and Engineering Division (PSE), Thuwal, \\ 23955-6900, Saudi Arabia \\ ${ }^{2}$ Desert Research Institute (DRI), Reno, Nevada 89512-1095, USA
}

Correspondence to: P. Jish Prakash (jishprakash@gmail.com)

Received: 3 February 2016 - Published in Atmos. Chem. Phys. Discuss.: 23 March 2016

Revised: 15 August 2016 - Accepted: 5 September 2016 - Published: 26 September 2016

\begin{abstract}
Both Moderate Resolution Imaging Spectroradiometer (MODIS) and Spinning Enhanced Visible and InfraRed Imager (SEVIRI) satellite observations suggest that the narrow heterogeneous Red Sea coastal region is a frequent source of airborne dust that, because of its proximity, directly affects the Red Sea and coastal urban centers. The potential of soils to be suspended as airborne mineral dust depends largely on soil texture, moisture content and particle size distributions. Airborne dust inevitably carries the mineralogical and chemical signature of a parent soil. The existing soil databases are too coarse to resolve the small but important coastal region. The purpose of this study is to better characterize the mineralogical, chemical and physical properties of soils from the Arabian Red Sea coastal plain, which in turn will help to improve assessment of dust effects on the Red Sea, land environmental systems and urban centers. Thirteen surface soils from the hot-spot areas of windblown mineral dust along the Red Sea coastal plain were sampled for analysis. Analytical methods included optical microscopy, X-ray diffraction (XRD), inductively coupled plasma optical emission spectrometry (ICP-OES), ion chromatography (IC), scanning electron microscopy (SEM) and laser particle size analysis (LPSA). We found that the Red Sea coastal soils contain major components of quartz and feldspar, as well as lesser but variable amounts of amphibole, pyroxene, carbonate, clays and micas, with traces of gypsum, halite, chlorite, epidote and oxides. The range of minerals in the soil samples was ascribed to the variety of igneous and metamorphic provenance rocks of the Arabian Shield forming the escarpment to the east of the Red Sea coastal plain. The analysis revealed that the samples contain compounds of nitrogen, phosphorus and iron that are essential nutrients to marine life. The analytical results from this
\end{abstract}

study will provide a valuable input into dust emission models used in climate, marine ecology and air quality studies.

\section{Introduction}

Mineral dust is the most abundant atmospheric aerosol, primarily suspended from soils in arid and semiarid regions of the globe (Buseck et al., 1999; Washington and Todd, 2005; Goudie and Middleton, 2006; Muhs et al., 2014), including deserts of the Arabian Peninsula (Edgell, 2006). Dust aerosols profoundly affect climate, biogeochemical cycles in the ocean and overland, air quality, atmospheric chemistry, cloud formation, visibility and human activities (Prospero et al., 2002; Haywood and Boucher, 2000; Hsu et al., 2004; Sokolik and Toon, 1999; Kumar et al., 2014; De Longueville et al., 2010; Jickells et al., 2005; Mahowald, 2009; Huang et al., 2006, 2014; Fryrear, 1981; Nihlen and Lund, 1995; Hagen and Woodruff, 1973; Bennett et al., 2006; Bennion et al., 2007; Twomey et al., 2011; Wang et al., 2010). The Arabian Peninsula is one of Earth's major sources of atmospheric dust, which contributes as much as $11.8 \%\left(22-500 \mathrm{Mta}^{-1}\right)$ of the total $\left(1877-4000 \mathrm{Mt} \mathrm{a}^{-1}\right)$ global dust emissions (Tanaka and Chiba, 2006). The Red Sea, surrounded by African and Arabian deserts, is strongly affected by dust. Along with profound impact on the surface energy budget over the land and the sea (Brindley et al., 2015; Kalenderski et al., 2013; Osipov et al., 2015), dust is an important source of nutrients especially for the oligotrophic northern Red Sea region (Acosta et al., 2013). Dust affects marine life and also controls incoming solar and terrestrial radiation. The coastal plains of the Arabian Peninsula along the Red Sea and Persian Gulf are among the most populated 
areas in this region, hosting the major industrial and urban centers.

Both Moderate Resolution Imaging Spectroradiometer (MODIS) and Spinning Enhanced Visible and InfraRed Imager (SEVIRI) satellite observations suggest that the narrow Red Sea coastal belt is an important dust source region, augmented by the fine-scale sediment accumulations, scattered vegetation and variable terrain. Dust hot spots are located within the narrow coastal region and, because of their proximity to the Red Sea, contribute to the dust-nutrient balance of the sea, during both dusty- and fair-weather conditions.

Dust emission rates from soils and sites of airborne particles strongly depend on the soil particle size distributions. Optical properties such as scattering, absorption and refractive indices vary by mineralogical content and particle size of the dust in the atmosphere. Dust reactivity in the seawater also depends on their mineralogy; for example carbonates (calcite, dolomite), evaporites (gypsum) and some oxides (hematite, goethite) are generally more soluble in water than, for example, most silicates (quartz, feldspars, micas, clays, amphiboles, pyroxenes). Soils in arid regions, where particles are only loosely bound to the surface by the low soil moisture, are most susceptible to wind erosion or being physically disturbed by agriculture or traffic. Dust uplifting occurs in a source region when the surface wind speed exceeds a threshold velocity (Gillette and Walker, 1977), which is a function of surface roughness elements, grain size and soil moisture (Marticorena and Bergametti, 1995; Wang et al., 2000). Fine soil particles that can be transported over large distances are released by saltating coarse silt and sand particles (Caquineau et al., 1997). Soil morphology, mineralogy and chemical composition define the abundance and composition of airborne dust, however, not directly but through the series of complex fine-scale nonlinear processes.

From preliminary observations it is estimated that five to six major dust storms per year impact the coastal region of Saudi Arabia, depositing about $6 \mathrm{Mt}$ of mineral dust into the Red Sea (Jish Prakash et al., 2015). Simulations and satellite observations suggest that the coastal dust contribution to the total deposition flux into the Red Sea could be significant even during fair-weather conditions (Jiang et al., 2009). However, the mineralogy, physical properties and chemical composition of dust generated from the Red Sea coastal region remain uncertain. The coastal plain is a narrow geographically and petrographically heterogeneous piedmont area and existing soil databases do not provide the spatial resolution for the region to be adequately described (Nickovic et al., 2012). The importance of keeping track of dust mineralogy during the atmospheric transport was recently recognized and implemented in models (Perlwitz et al., 2015b, a). Equation (1) relates the size-dependent soil dust properties with that emitted into the atmosphere, where dust-size distribution and compositional characteristics are further adjusted as the atmospheric residence time of dust particles depends on their particle size distribution and particle mass. To explain the connection between soil properties and airborne dust abundance and composition we discuss the physically based dust generation parameterizations currently used in the advanced modeling systems (Grell et al., 2005; Zender et al., 2003). The vertical mass flux $F_{j}\left(\mathrm{~kg} \mathrm{~m}^{-2} \mathrm{~s}^{-1}\right)$, with dust-size component $j$, generated from the ground to the atmosphere can be assessed as follows:

$F_{j}=T S f_{\mathrm{m}} \alpha Q_{\mathrm{s}} \sum_{i=1}^{I} M_{i j}$,

where $T$ is a tuning constant for adjusting to different horizontal and temporal resolutions. The parameter $S$ is the erodibility factor that accounts for the susceptibility of a landscape to wind erosion controlled by the non-erodible roughness elements and the erodibility of soils within the erodible area of a landscape (Webb and Strong, 2011). This parameter is often defined via the so-called "source function" that accounts for the spatial distribution of dust source intensities based on a variety of algorithms (Menut et al., 2013). The parameter $f_{\mathrm{m}}$ is a grid cell fraction of exposed bare soil suitable for dust mobilization. The coefficient $\alpha$ is the sandblasting mass efficiency determined by the mass fraction of clay particles in the soil. The parameter $Q_{\mathrm{s}}$ is the total horizontally saltation mass flux $\left(\mathrm{kg} \mathrm{m}^{-1} \mathrm{~s}^{-1}\right)$, which is proportional to the third power of friction velocity $\left(u_{\mathrm{s}}^{*}\right)$ when it exceeds a threshold velocity $u_{t}^{*}$ (Oleson et al., 2010; Zender et al., 2003). In dust emission models, the soil erodibility is represented through the effects of soil texture and moisture content on the threshold friction velocity $u_{t}^{*}$ and the aerodynamic roughness length $f_{z}$ (Oleson et al., 2010; Webb and Strong, 2011). $M_{i j}$ is the mass fraction of each source mode $i$, carried in each transport bin $j$.

The sample area in this study lies within the approximately $60-70 \mathrm{~km}$ wide Tihāmah coastal plain, comprised of the Tihāmat 'Asīr in the south and the Tihāmat Al-Hejaz to the north. The plain is bounded by the Red Sea in the west, with the mountains of Midyan, Ash Shifa and Asir forming an escarpment to the east (Edgell, 2006), with few breaks in the mountains in the northwest. The mountains form a 1000-3000 m elevation Red Sea escarpment, comprised of igneous, metamorphic and volcanic rocks of variable age, from the Precambrian (1000-545 Ma) to less than $30 \mathrm{My}$ in age (Grainger, 2007). The Red Sea rift basin itself is overlain by the much younger sediments of the Quaternary age $(<2.6 \mathrm{Ma})$.

Al-Farraj (2008) studied the soils from the Jīzān region of southern Saudi Arabia, identifying smectite, kaolinite and illite as the predominant clay minerals, together with lesser amounts of chlorite, quartz and feldspars. Shadfan et al. (1984) investigated mineralogical content and general characteristics of soils from some agricultural areas in Saudi Arabia. They found carbonate, quartz and gypsum to be the main constituents of the sand and silt fractions in soils of the eastern region, while quartz, carbonate and feldspars dom- 
inate soils in the central region. The soils in the west contain mainly quartz, feldspars, hornblende and mica. Palygorskite was found to be the main clay mineral in soils in the eastern region; kaolinite in the central region; and kaolinite, smectite and mica in the western region. Aba-Husayn et al. (1980) mineralogically analyzed soils from the southwestern region of Saudi Arabia, along the mountainous Asir region between Mecca and Abha. They found large amounts of quartz, feldspars and micaceous minerals in the silt fractions, with the clay-size fractions of kaolinite, smectite and vermiculite, and with kaolinite in the well-drained highland areas. Viani et al. (1983) studied 14 soils from alluvial basins in the Wādī ad Dawāsir and Wādī Najrān areas of southwestern Saudi Arabia. Due to the fact that the alluvial claysize fractions were from weathered igneous rocks of the surrounding mountains, they were found to be composed largely of smectite, mica, kaolinite, chlorite, palygorskite and vermiculite. With the exception of the area around Jizzān in the south, which is impacted by the Indian Ocean monsoon, the Red Sea coastal region has a desert climate characterized by extreme heat, reaching $39^{\circ} \mathrm{C}$ during the summer days, with a drop in nighttime temperatures by approximately $10^{\circ} \mathrm{C}$. Although the extreme temperatures are moderated by the proximity of the Red Sea, in summer the humidity is often $85 \%$ or higher during periods of the northwesterly shamal winds. Annual rainfall decreases in a northwardly direction; from an annual average of $133 \mathrm{~mm}$ at Jīzān in the south, to $56 \mathrm{~mm}$ at Jeddah in central Saudi Arabia, and $24 \mathrm{~mm}$ at Tabūk in the north. Vegetation is sparse, being restricted to semidesert shrubs and acacia trees along the ephemeral rivers (wadis), and provides forage for small herds of goats, sheep and dromedary camels.

During infrequent but severe rainstorms, run-off from the escarpment along wadis often produces flash floods. With such events, fine silt and clays are deposited on the coastal plain, which are transformed into dust sources during dry and windy periods of the year. The resultant dust is transported and deposited on the coastal plain and adjacent Red Sea by prevailing northwesterly to southwesterly winds, with moderate breezes (wind speed $>5.5 \mathrm{~m} \mathrm{~s}^{-1}$ ) from the north (http://www.windfinder.com/weather-maps/report/ saudiarabia\#6/22.999/34.980).

\section{Objectives}

The assumption is that at least part of the dust in the ambient atmosphere in the coastal region is from windblown and otherwise disturbed soils along the Red Sea coast. Jiang et al. (2009) and Kalenderski et al. (2013) found that the coastal area emits about 5-6 Mt of dust annually. Due to its close proximity, a significant portion of this dust is likely to be deposited into the Red Sea, and this amount could be comparable to the estimated annual deposition rate from remote sources during major dust storms (Jish Prakash et al., 2015).

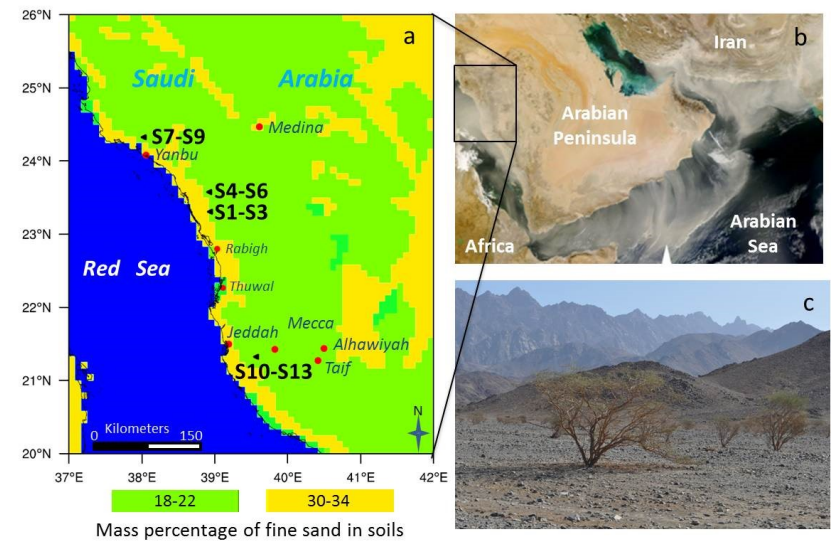

Figure 1. (a) Map showing the mass percentage of fine sand in soils, based on STATSGO-FAO soil-texture data (Nickovic et al., 2012; Menut et al., 2013), in the Arabian Peninsula, as well as the four localities and 13 (S1-S13) sampling sites. (b) MODIS satellite image of dust storm over the Arabian Peninsula captured on 22 February 2008 (NASA MODIS web site). (c) Sampling site S1 showing the typical acacia trees growing along the wadi in the foreground, with the Hijaz mountain range and escarpment in the distance.

Due to the limited compositional information of soils along the Red Sea coastal region, this study aims to provide mineralogical, chemical and morphological information on soils (Scheuvens and Kandler, 2014) within the central part of the Red Sea coastal plain of Saudi Arabia (Fig. 1).

This information will help to better quantify the ecological impacts, health effects, damage to property and optical effects of dust blown from these areas (Engelbrecht et al., 2009a, b; Weese and Abraham, 2009). The mineralogical compositions of the soils tie into that of the parental rocks, weathering conditions and time. This research will also complement soil and dust studies performed in the Arabian Peninsula as well as globally (Engelbrecht and Moosmüller, 2014; Engelbrecht et al., 2009b). Knowledge of the mineralogy of the soils will provide data on refractive indices, particle size and shape parameters, which can be used to calibrate dust transport models and help to assess the impact of dust events on the coastal plain and the Red Sea.

\section{Sampling and analysis}

A total of 13 samples were collected at four localities along the Red Sea coastal plain (Fig. 1). Three samples, S1-S3, were collected at $25 \mathrm{~km}$ northeast of Mastūrah near washland of Wādī Hazāhiz, located $26 \mathrm{~km}$ from the Red Sea. Samples S4-S6 were collected at $30 \mathrm{~km}$ east of Ar Rāyis near 'Ushash, which is a village in the Al Madināh province that is located $32 \mathrm{~km}$ from the Red Sea. Samples S7-S9 were collected at $27 \mathrm{~km}$ north of Yanbu at washland of Wādī al Wazrah with an elevation of $158 \mathrm{~m}$ above sea level and located $30 \mathrm{~km}$ from the Red Sea. Four samples, S10-S13, were 
collected at $28 \mathrm{~km}$ southwest of Mecca near Wādī An Numan, located $45 \mathrm{~km}$ from the Red Sea. The coordinates of the sample sites are provided in Table 1. All 13 samples can be classed as Leptosols (Regosols) (http://www.fao.org/ag/ $\mathrm{agl} / \mathrm{ag} 11 / \mathrm{wrb} / \mathrm{soilres} . \mathrm{stm})$.

The grab soil samples collected in the field were sieved to $<1 \mathrm{~mm}$ to remove pebbles, plant material and other detritus. Where necessary, they were air-dried in the laboratory before being labeled, catalogued and stored in capped plastic bottles. Subsets of these samples were screened to $<38 \mu \mathrm{m}$ for mineral analysis by powder X-ray diffraction (XRD), chemical analysis and scanning electron microscopy (SEM)-based individual particle analysis. Further samples of $>75,<125 \mu \mathrm{m}$ were sieved for mineralogical investigation by optical microscopy and $<600 \mu \mathrm{m}$ for laser particle size analysis (LPSA).

Petrographic microscopy is particularly suited to the optical identification of mineral grains larger than approximately $10 \mu \mathrm{m}$ (Kerr, 1959). It remains a cost-effective and accurate technique to obtain mineralogical information which is otherwise difficult to obtain, e.g. the identification of feldspars, amphiboles and pyroxenes. The $>75,<125 \mu \mathrm{m}$ sieved soil fraction grains were mounted on epoxy on a glass slide and ground to a thickness of approximately $30 \mu \mathrm{m}$ for transmitted light optical microscopy. Minerals with distinctive optical properties - including refractive indices, birefringence, extinction angles, pleochroism and optical interference patterns, or those showing twinning, distinctive cleavage and diagnostic extinction angles - can be readily be identified by optical microscopy (Kerr, 1959). Minerals readily identified in these samples by this method include quartz, various feldspars, amphiboles, pyroxenes, micas and carbonates. However, depending on the mineral type, particles $<10 \mu \mathrm{m}$ in diameter are often difficult to identify by this method, including clay minerals and other layered silicates. The method is biased towards easily identifiable and coarser minerals, especially those with twinning, such as feldspars, and showing color and pleochroism, such as hornblende and biotite. The method, although one of the most practical for qualitative mineral analysis, does require mineralogical expertise.

$\mathrm{X}$-ray diffraction is a nondestructive technique for characterization of minerals. Powder XRD is particularly suited for fine-grained crystalline mineral mixtures $<10 \mu \mathrm{m}$ in diameter. The procedure measures the crystallinity of a sample, i.e. excludes amorphous phases such as clay-like colloids (Formenti et al., 2011; Leinen et al., 1994; Engelbrecht et al., 2016; Kandler et al., 2009), partly crystalline layered silicates such as some clays, and hydroxides. If an amorphous phase is present, it will not be fingerprinted by XRD. The assessment of mineral content of a powder sample by the relative intensity ratio (RIR) method suggested by Chung (1974), and as applied in our measurements, does not account for amorphous content. Dust reactivity in seawater, as well as its optical properties, depends on its mineralogy, for example, carbonates and some silicates are generally more soluble in
Table 1. Localities of soil sampling sites along the Red Sea coastal plain.

\begin{tabular}{llrrr}
\hline Site & Locality & Latitude & Longitude & Elevation (m) \\
\hline S1 & SE of Al Nasaif & $23.3322^{\circ} \mathrm{N}$ & $38.9481^{\circ} \mathrm{E}$ & 94 \\
S2 & SE of Al Nasaif & $23.2961^{\circ} \mathrm{N}$ & $38.9385^{\circ} \mathrm{E}$ & 68 \\
S3 & SE of Al Nasaif & $23.2920^{\circ} \mathrm{N}$ & $38.9100^{\circ} \mathrm{E}$ & 46 \\
S4 & E of Ar Rāyis & $23.5876^{\circ} \mathrm{N}$ & $38.9243^{\circ} \mathrm{E}$ & 128 \\
S5 & E of Ar Rāyis & $23.5746^{\circ} \mathrm{N}$ & $38.9213^{\circ} \mathrm{E}$ & 118 \\
S6 & E of Ar Rāyis & $23.5656^{\circ} \mathrm{N}$ & $38.9193^{\circ} \mathrm{E}$ & 115 \\
S7 & N of Yanbu & $24.3334^{\circ} \mathrm{N}$ & $38.0205^{\circ} \mathrm{E}$ & 113 \\
S8 & N of Yanbu & $24.3239^{\circ} \mathrm{N}$ & $38.0254^{\circ} \mathrm{E}$ & 60 \\
S9 & N of Yanbu & $24.3195^{\circ} \mathrm{N}$ & $38.0245^{\circ} \mathrm{E}$ & 56 \\
S10 & SW of Mecca & $21.3197^{\circ} \mathrm{N}$ & $39.5763^{\circ} \mathrm{E}$ & 128 \\
S11 & SW of Mecca & $21.3232^{\circ} \mathrm{N}$ & $39.5711^{\circ} \mathrm{E}$ & 124 \\
S12 & SW of Mecca & $21.3211^{\circ} \mathrm{N}$ & $39.5593^{\circ} \mathrm{E}$ & 133 \\
S13 & SW of Mecca & $21.3253^{\circ} \mathrm{N}$ & $39.5508^{\circ} \mathrm{E}$ & 118 \\
\hline
\end{tabular}

water than, for example, feldspars, amphiboles, pyroxenes or quartz. A Bruker D ${ }^{\circledR}$ powder XRD system was used to analyze the mineral content of the soil samples. The diffractometer was operated at $40 \mathrm{kV}$ and $40 \mathrm{~mA}$, with $\mathrm{Cu} \mathrm{K} \alpha$ radiation, scanning over a range of $4^{\circ}$ to $50^{\circ} 2 \theta$. The Bruker TOPAS ${ }^{\circledR}$ software using the RIR method was applied for semiquantitative XRD analyses of the $<38 \mu \mathrm{m}$ screened dust samples (Rietveld, 1969; Chung, 1974; Esteve et al., 1997; Caquineau et al., 1997; Sturges et al., 1989).

Laser particle size analysis (LPSA) was performed on the 13 soil samples. The LPSA system measures the size-class fractions of a soil or sediment sample in an aqueous suspension, based on the principle that light scatters at angles inversely proportional to, and with intensity directly proportional to, particle size (Gee and Or, 2002). The grab samples were sieved to $<600 \mu \mathrm{m}$ before being introduced to the laser analyzer (Micromeritics Saturn DigiSizer $5200^{\circledR}$ ) in an aqueous solution of $0.005 \%$ surfactant (sodium metaphosphate). The suspensions were internally dispersed by applying ultra-sonication, before being circulated through the path of the laser light beam. The measured size-class fractions were grouped as clay $(<2 \mu \mathrm{m})$, silt $(>2,<62.5 \mu \mathrm{m})$ and sand $(>62.5,<600 \mu \mathrm{m})$ (Engelbrecht et al., 2012). This analytical method disperses soil aggregates which are potential dust particles, thus shifting the particle size distribution curves towards the smaller particle sizes. This may introduce a bias to the actual size distribution of wind-generated dust particles in the field.

The $<38 \mu \mathrm{m}$ sieved samples were chemically analyzed for elemental composition by inductively coupled plasma optical emission spectrometry (ICP-OES) and their water-soluble ions by ion chromatography (IC). For ICP-OES, splits of $0.1 \mathrm{~g}$ of each of the samples were digested in a 1:3:1 mixture of concentrated $\mathrm{HF}, \mathrm{HCl}$ and $\mathrm{HNO}_{3}$ in a microwave oven (Milestone Ethos $1^{\circledR}$ ) operated at a temperature of up to $195^{\circ} \mathrm{C}$ for $15 \mathrm{~min}$. The solutions were diluted from 25 to $250 \mathrm{~mL}$ before being analyzed using ICP-OES (Varian 720$\left.\mathrm{ES}^{\circledR}\right)$, for $\mathrm{Na}, \mathrm{Mg}, \mathrm{Al}, \mathrm{Si}, \mathrm{P}, \mathrm{S}, \mathrm{K}, \mathrm{Ca}, \mathrm{Ti}, \mathrm{V}, \mathrm{Cr}, \mathrm{Mn}, \mathrm{Fe}, \mathrm{Co}$, 
$\mathrm{Ni}, \mathrm{Cu}, \mathrm{Zn}, \mathrm{Sr}, \mathrm{Cd}, \mathrm{Ba}$ and $\mathrm{Pb}$. The accuracy of the analyses was monitored by analyzing the National Institute of Standards and Technology (NIST) standard reference material 1646a with each batch of soil samples. The elemental composition of dust per se does not provide adequate information on its mineral content. However, with a priori knowledge of the mineral composition of the samples, from optical and XRD measurements, "normative" mineral compositions can be calculated. This provides a method for inter-comparing chemically analyzed samples with each other.

Further splits $(\sim 0.01 \mathrm{~g})$ of the $<38 \mu \mathrm{m}$ sieved samples were sonicated in $15 \mathrm{~mL}$ deionized, distilled water, the suspension left to settle overnight and the extractions analyzed by IC (DIONEX ICS-3000 ${ }^{\circledR}$ ). The water-soluble cations of sodium $\left(\mathrm{Na}^{+}\right)$, potassium $\left(\mathrm{K}^{+}\right)$, calcium $\left(\mathrm{Ca}^{2+}\right)$ and magnesium $\left(\mathrm{Mg}^{2+}\right)$ and anions of sulfate $\left(\mathrm{SO}_{4}^{2-}\right)$, chloride $\left(\mathrm{Cl}^{-}\right)$, phosphate $\left(\mathrm{PO}_{4}^{3-}\right)$ and nitrate $\left(\mathrm{NO}_{3}^{-}\right)$were analyzed by this method.

Electron microscopy provides information on the individual particle size, shape, chemical composition and mineralogy of micron-size particles, which is important for determining the optical parameters for modeling of dust (Moosmüller et al., 2012). The individual particle chemistry, especially of the soluble minerals such as carbonates, is often of importance in medical geology and to marine life. The SEM-based individual particle analysis was performed on the $<38 \mu \mathrm{m}$ sieved sample splits. A dual approach was followed, the first being the computer-controlled scanning electron microscopy (CCSEM) and the second being secondary electron imaging by high-resolution SEM. For each sample, a portion of soil was suspended in isopropanol and dispersed by sonication. The suspension was vacuum-filtered onto a $0.2 \mu \mathrm{m}$ pore-size polycarbonate substrate. A section of the substrate was mounted onto a metal SEM stub with colloidal graphite adhesive. The sample mounts were sputtercoated with carbon to dissipate the negative charge induced on the sample by the electron beam. The automated CCSEM analysis was conducted on a Tescan MIRA $3^{\circledR}$ field emission scanning electron microscope (FE-SEM). The CCSEM analysis was performed by rastering the electron beam over the sample while monitoring the resultant combined backscattered electron (BE) and secondary electron (SE) signals. The $\mathrm{BE}$ intensities were applied to set grayscale levels in order to distinguish particles of interest from the background. The system was configured to automatically measure the size and the elemental composition for approximately 2000 individual particles of $>0.5,<38 \mu \mathrm{m}$ sizes. Individual particles were classified into particle types according to their elemental compositions. A digital image was acquired of each particle, for measurement, and stored for subsequent review. Size measurements were based on diameters obtained from the projected area of each particle by tracing their outer edges. Compositional information was determined through collection and processing of characteristic X-rays by energy dis-
Table 2. The volume particle size fraction (\%) of the $<600 \mu \mathrm{m}$ sieved soil samples.

\begin{tabular}{lrrr}
\hline Sample & $\begin{array}{r}\text { Sand } \\
(600-62.5 \mu \mathrm{m})\end{array}$ & $\begin{array}{r}\text { Silt } \\
(62.5-2 \mu \mathrm{m})\end{array}$ & $\begin{array}{r}\text { Clay } \\
(<2 \mu \mathrm{m})\end{array}$ \\
\hline S1 & 78.0 & 19.2 & 2.8 \\
S2 & 77.2 & 20.5 & 2.3 \\
S3 & 93.3 & 5.7 & 1.0 \\
S4 & 96.3 & 3.0 & 0.7 \\
S5 & 88.4 & 10.0 & 1.7 \\
S6 & 88.5 & 9.8 & 1.6 \\
S7 & 94.3 & 5.2 & 0.5 \\
S8 & 93.5 & 6.0 & 0.5 \\
S9 & 87.1 & 12.1 & 0.9 \\
S10 & 87.8 & 10.6 & 1.6 \\
S11 & 86.6 & 11.4 & 1.9 \\
S12 & 91.1 & 7.6 & 1.2 \\
S13 & 92.7 & 6.1 & 1.2 \\
\hline
\end{tabular}

persive spectroscopy (EDS) using a silicon drift detector. The elements identified in the spectrum were processed to obtain their relative concentrations. The particles were grouped into "bins" by their particle size and chemical ratios. From the chemical measurements and a priori knowledge of the sample mineralogy (from optical microscopy and XRD), the mineralogy of individual particles can often be inferred, e.g. $\mathrm{Si}$ particles being quartz, $\mathrm{Ca}$ particles being calcite, and $\mathrm{Ca}$ plus $\mathrm{S}$ particles being gypsum. Due to the attenuation of the electron beam as it impinges the particle surface and loss of energy, the analysis is physically limited to an electron interaction volume of 2-5 $\mu \mathrm{m}$ below the mineral surface depending on the primary beam voltage and the mineral density (Goldstein et al., 2003). Most of the investigated mineral dust particles have coatings of clay minerals and oxides, which results in an overestimation of the amounts of these minerals when analyzed by CCSEM (Engelbrecht et al., 2009a, b, 2016).

The field emission electron source allows for high magnifications and sharp secondary electron images (SEIs). This technique allows for the detailed study of particle shape, surface features and chemical compositions. Approximately five SEIs with energy dispersive spectra (EDS) for each of the 13 samples were collected. Supplement S03 shows a few SEM, SEIs and EDS spectra of the $<38 \mu \mathrm{m}$ soil particles from the sampling site.

\section{Results}

\subsection{Particle size analysis}

Particle volume size plots of the $<600 \mu \mathrm{m}$ sieved samples are listed in Table 2 and graphically presented in Fig. 2. The 13 soils are composed of, on average, close to $89 \%$ sand 


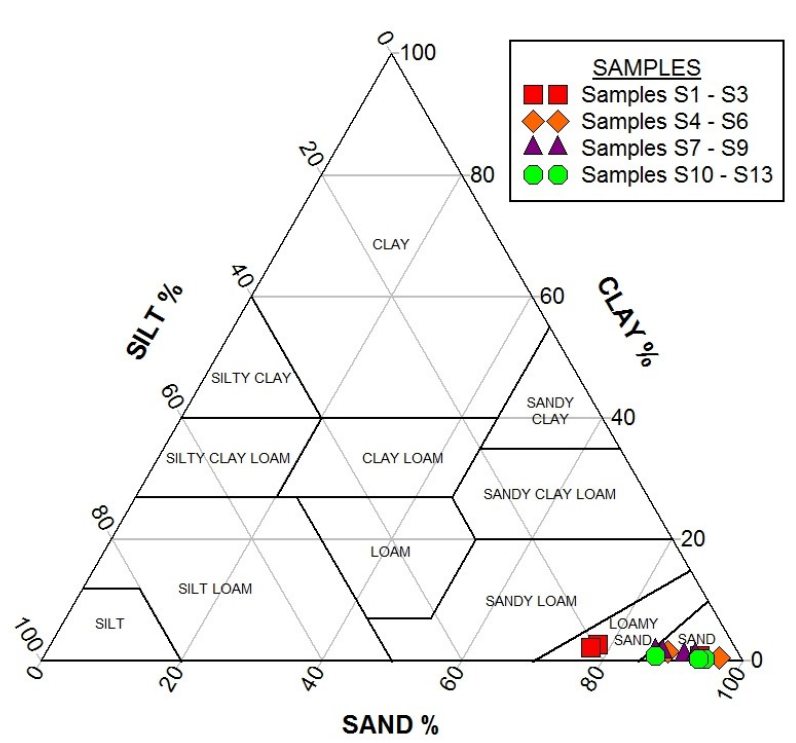

Figure 2. US Department of Agriculture (USDA) soil-texture triangle showing the grain size plot of the 13 samples collected for this study. Volume size-class fractions grouped as clay $(<2 \mu \mathrm{m})$, silt $(2-$ $62.5 \mu \mathrm{m})$ and sand $(62.5-600 \mu \mathrm{m})$.

fractions. Also, the silt makes up approximately $10 \%$ and the clay on average less than $1.5 \%$ of the sample volume.

Field and laboratory measurements of dust from the western USA carried out by Engelbrecht et al. (2012) showed that dust emissions are largely controlled by their soil particle size distributions (Kok, 2011a, b). It was established that surface soils with a silt content greater than approximately $50 \%$ and a clay content of less than approximately $10 \%-$ i.e. samples in the "silt loam" field (Fig. 2) - have the greatest potential to become resuspended in the air and to generate airborne mineral dust. This particle size criterion provides an important measure for whether a site or region has the potential to be a significant dust source (Greely and Iversen, 1985). These include soils from previously identified dust sources such as; the Bodélé Depression (Washington et al., 2003); loess along the Danube River valley, Kuwait and China (Engelbrecht and Moosmüller, 2014); silt deposits collected on the island of Fuerteventura assumed to contain dust from the western Sahara (Menéndez et al., 2014); and one diatomaceous silt sample from Reno, USA. Besides the particle size distribution, it was shown that moisture content and surface roughness play important roles in the saltation and desegregation of soil particles (Marticorena, 2014). Judging from their particle size distributions alone, soil samples collected from the coastal zone of Saudi Arabia are not considered to contain enough silt-size particles to be efficient emitters of dust. However, the satellite images show that these coastal dust sources are activated quite frequently.

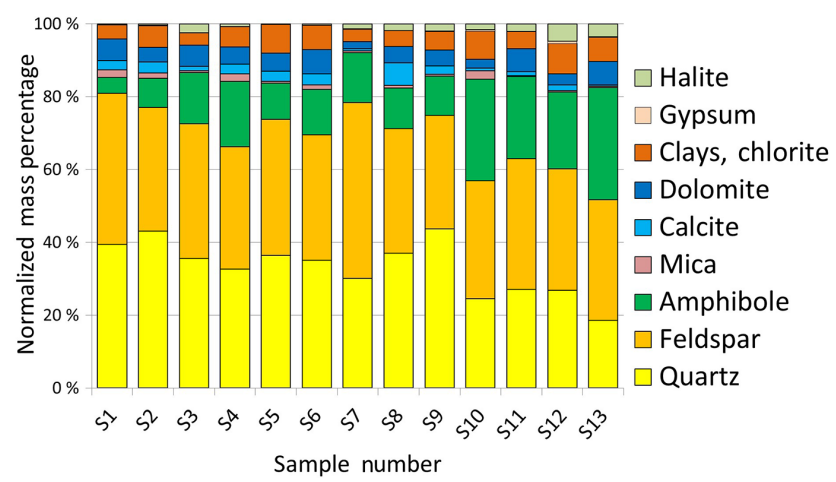

Figure 3. Normalized mineral compositions by percentage of mass of 13 sieved soil samples $<38 \mu \mathrm{m}$ collected at four localities along the Red Sea coastal area, as measured by XRD.

\subsection{Optical microscopy}

Mineralogical investigation by optical microscopy of three $>75,<125 \mu \mathrm{m}$ sieved samples showed them to consist of partially weathered angular mineral grains in sediments probably eroded from the Precambrian basement and Tertiary volcanic rocks of the Arabian Shield, approximately $50 \mathrm{~km}$ east of the Red Sea coastline (Edgell, 2006). The major minerals identified in this size range are feldspar (mainly plagioclase), quartz, pyroxene (aegirine-augite), amphibole and mica (biotite, muscovite). Lesser amounts of potassium feldspar (orthoclase, microcline), carbonates (calcite, dolomite), chlorite, epidote and oxides were identified by optical microscopy.

\subsection{XRD mineral analysis}

XRD analysis of the 13 sieved samples $<38 \mu \mathrm{m}$ (Fig. 3) from the Red Sea coastal plain confirmed variable mass percentages of quartz (19-44\%) and feldspars (plagioclase, Kfeldspar) (31-48\%), as well as of amphibole (and pyroxene) (4-31\%), with lesser amounts of calcite (0.4-6.2\%), dolomite (1.9-6.6\%), clays (smectite, illite, palygorskite, kaolinite) and chlorite (3.3-8.3\%), and with traces of gypsum $(0-0.6 \%)$ and halite $(0.2-4.8 \%)$. The average amphibole (plus pyroxene) content for the four samples taken at the southernmost locality (Fig. 1, S10-S13) is substantially higher than for the nine samples taken at the other three localities (Fig. 1, S1-S9), approximately $26 \%$ and $11 \%$, respectively. For the southernmost locality and other localities, the mineralogy resembles that of the igneous and metamorphic rocks of the adjacent mountainous escarpment and Arabian Shield (Edgell, 2006). This can be attributed to differences in the mineral composition of the Arabian Shield rocks, the distance of the sampling sites from the source regions and the extent of weathering in the surface soils. 


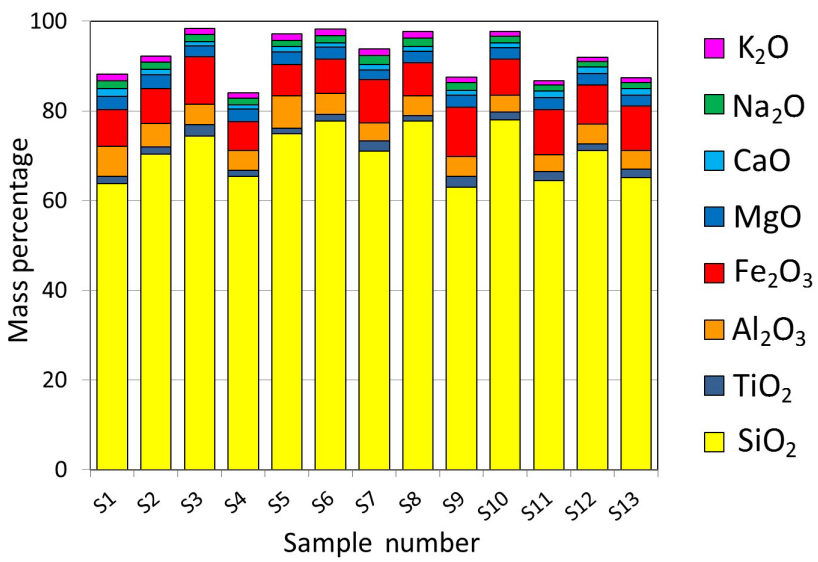

Figure 4. Compositional plot showing major oxide percentages by mass from ICP-OES analysis of $<38 \mu \mathrm{m}$ sieved soils.

\subsection{Chemistry (ICP-OES and IC)}

Chemical analysis of the $<38 \mu \mathrm{m}$ sieved bulk samples by ICP-OES and IC is presented in Appendix A, Tables A1 and $\mathrm{A} 2$, and a plot of the major elements expressed as oxides, shown in Fig. 4. The soils are of reasonably consistent chemical composition throughout the sampled region.

The sedimentary samples all contain major mass percentages of $\mathrm{SiO}_{2}$, which varies between 63 and $78 \%$ in the 13 samples, mostly as the mineral quartz, and lesser mass percentages of $\mathrm{Al}_{2} \mathrm{O}_{3}, \mathrm{CaO}, \mathrm{Na}_{2} \mathrm{O}$, and $\mathrm{K}_{2} \mathrm{O}$ in plagioclase and potassium feldspars. $\mathrm{SiO}_{2}$ together with $\mathrm{Al}_{2} \mathrm{O}_{3}, \mathrm{Fe}_{2} \mathrm{O}_{3}$, $\mathrm{TiO}_{2}, \mathrm{MnO}, \mathrm{MgO}$ and some $\mathrm{K}_{2} \mathrm{O}$ is also contained in the previously identified clays, micas and amphiboles. Small amounts of $\mathrm{CaO}(0.9-1.7 \%)$ are contained in gypsum and calcite, and are found together with $\mathrm{MgO}(2.3-3.1 \%)$ in dolomite.

The water-soluble ions account for a small percentage of the total mass of the soils, varying between 0.1 and $0.7 \%$ for the total cations and 0.03 and $0.8 \%$ for the total anions. These account primarily for calcite and dolomite $(\sim 0.3 \%)$ and gypsum $(\sim 0.2 \%)$, with even lesser amounts of halite and other chlorides from sea salt. The unexpectedly low concentration of halite and other soluble salts in the soils of the coastal plains can be ascribed to the fact that all the samples were collected at distances varying between 21 and $42 \mathrm{~km}$ from the Red Sea coast, and also the absence of local playas or other saline soils close to the four sampled areas. It is also expected that the salts had been leached from the soil samples collected from the surface. Also of importance to dust-borne nutrients that are likely to be deposited in the Red Sea is the low concentration of water-soluble $\mathrm{PO}_{4}^{3-}$ (avg. $0.003 \%$ ) in comparison to the total $\mathrm{P}_{2} \mathrm{O}_{5}$ (avg. $0.4 \%$ ) in the soils. The phosphorus is largely bound in the low-solubility mineral apatite (francolite), commonly found in the sediments throughout the Arabian Peninsula.

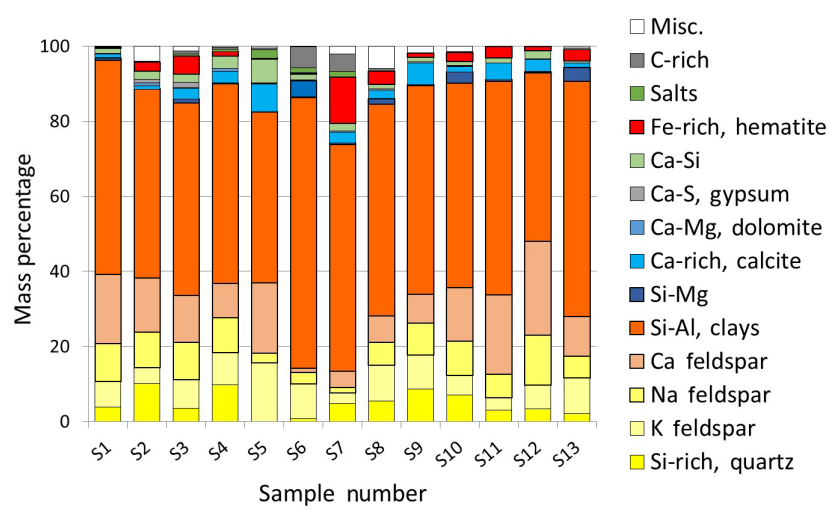

Figure 5. CCSEM-based individual particle analysis for the 0.5$38 \mu \mathrm{m}$ chemical set, with the chemical bins labeled as minerals, arranged by normalized mass percentage.

The $\mathrm{Fe} / \mathrm{Al}$ mass ratios for the suite of 13 samples from the Red Sea coastal plain vary between 1.26 and 3.59, with a geometric mean of 2.41 (Appendix A). These measurements partly overlap with the $\mathrm{Fe} / \mathrm{Al}$ ratios of 0.53-1.71 measured for dust samples from the Bodélé Depression in Chad (Bristow et al., 2010) and are included in the range of 0.41-3.78 for resuspended soil samples from global dust sources (Engelbrecht et al., 2016). In contrast, soil samples collected from ferricretes along the southern Sahel in northern Africa have $\mathrm{Fe} / \mathrm{Al}$ ratios in the range of 2.95 to 3.43 (Roquin et al., 1990).

\subsection{SEM chemical analysis}

Approximately 2000 individual dust particles per sample in the $0.5-38 \mu \mathrm{m}$ size range were analyzed automatically by CCSEM for chemical composition, particle morphology and size. The particles were classed into 14 bins as per their chemical compositions. Mineral labels were assigned to these chemical bins, e.g. Fe-rich as hematite $\left(\mathrm{Fe}_{2} \mathrm{O}_{3}\right)$ (also possibly goethite, magnetite or ferrihydrite), $\mathrm{CaS}$-rich as gypsum $\left(\mathrm{CaSO}_{4} \cdot 2 \mathrm{H}_{2} \mathrm{O}\right), \mathrm{CaMg}$-rich as dolomite $\left(\mathrm{CaMg}\left(\mathrm{CO}_{3}\right)_{2}\right)$, Ca-rich as calcite $\left(\mathrm{CaCO}_{3}\right)$, CaAlSi-rich as anorthite $\left(\mathrm{CaAl}_{2} \mathrm{Si}_{2} \mathrm{O}_{8}\right)$, NaAlSi-rich as albite $\left(\mathrm{NaAlSi}_{3} \mathrm{O}_{8}\right)$, $\mathrm{KAlSi}$-rich as K-feldspar $\left(\mathrm{KAlSi}_{3} \mathrm{O}_{8}\right)$ and Si-rich as quartz $\left(\mathrm{SiO}_{2}\right)$. The CCSEM results for the $0.5-38 \mu \mathrm{m}$ analyzed set as well as the $0.5-2.5 \mu \mathrm{m}$ (fine) subset are presented in Figs. 5 and 6.

For the total data set, the samples in the $0.5-38 \mu \mathrm{m}$ size range contain, by mass, approximately $0.1-10.2 \%$ quartz, 5-54 \% feldspar and 45-72\% clay minerals as major components, with lesser amounts of calcite, dolomite, gypsum and iron oxides. The clay minerals can occur as individual minerals but largely as coatings on other silicates (Engelbrecht et al., 2009a). The $0.5-38 \mu \mathrm{m}$ set shows a substantial variability in chemical composition but no distinct differences between the samples within the four localities. The $0.5-2.5 \mu \mathrm{m}$ (fine) 


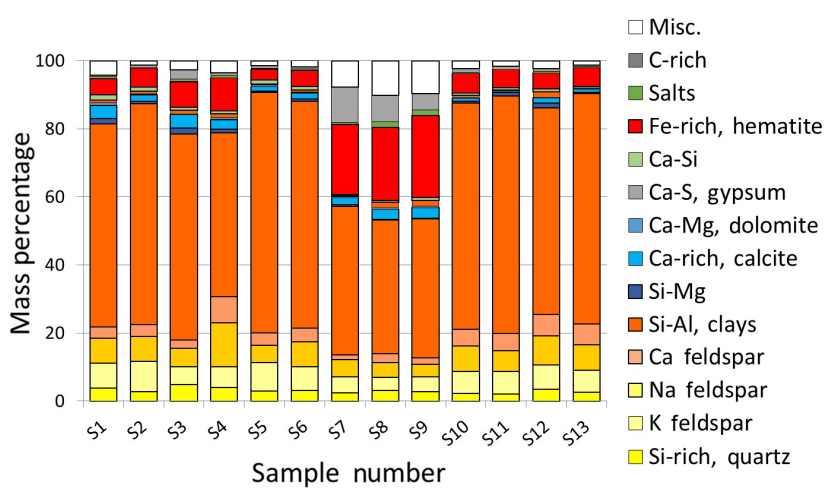

Figure 6. CCSEM-based individual particle analysis for $0.5-2.5 \mu \mathrm{m}$ (fine) subset, with the chemical bins labeled as minerals, arranged by normalized mass percentage.

subsets of the three samples (S7, S8 and S9) are different from the others in their higher Fe-rich (goethite, hematite) and carbon (carbonates) components, as well as their corresponding smaller amounts of clay (Fig. 6). This can be ascribed to a local difference in the mineralogical composition of the undifferentiated source rocks (Edgell, 2006), as well as weathering conditions.

The size and shapes of the 13 sieved samples $<38 \mu \mathrm{m}$ are given in Appendix A and Tables A1 and A2, with the average size distributions graphically displayed in Fig. 7. For individual samples, the particle sizes are approximately log-normally distributed (skewness 2.3-5.5), often showing a slight bimodality, with a small maximum (approx. $12 \mu \mathrm{m}$ ) on the high end of the distributions. The latter can be ascribed to harder and larger silt size particles of quartz and feldspars. The greatest number of particles are tightly clustered about their mean diameters, resulting in high but variable kurtosis values (4.6-44.0). The geometric mean diameters for the particles lie in the small range of $2.1-3.7 \mu \mathrm{m}$, implying similar mineralogy and hardness. The mean aspect ratios of the particles also fall in a tight range of 1.40-1.48, with a mean value of 1.43 .

\section{Summary and conclusions}

The impact of soil dust from natural and anthropogenic sources on climate and air quality has been recognized on a global scale (Sokolik and Toon, 1996; Tegen and Fung, 1995). However, the regional fine-scale processes of mineral dust emissions and their effect on environmental processes and human health are poorly quantified in the study region because of the spatial distribution of detailed mineralogical, physical and chemical properties of the surface soils at coastal dust source regions ("hot spots") that were previously not available.

The application of a range of techniques for the analysis of properties of soil samples allows for a better understand-

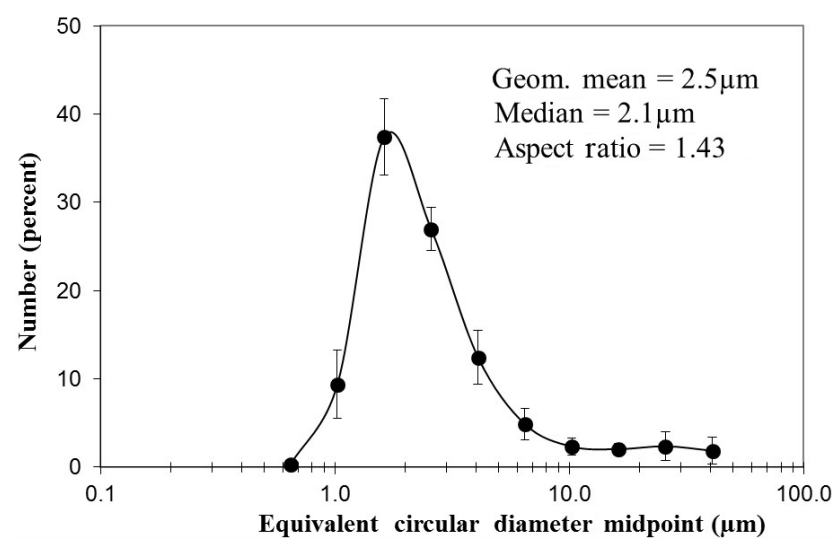

Figure 7. Average and standard deviations of particle sizes, as well as size and shape statistics for 13 sieved samples $<38 \mu \mathrm{m}$ as measured by CCSEM.

ing of mineral dust. However, the different analytical methods often provide different results, as seen by comparing the $\mathrm{XRD}$, electron microscopy and chemistry of the soils. In this study, the results from the XRD analysis gives a quartz percentage of between approximately 19 and $44 \%$ and sheet silicates (clays, micas) of between approximately 3 and $8 \%$. In contrast, the single particle analysis by CCSEM gives a quartz fraction of only up to approximately $10 \%$, whereas the sheet silicates always have the largest mineral percentage, of up to approximately $72 \%$. This can lead to ambiguity in the interpretation of the mineralogical composition of the samples, which is evident even where the mineral composition is investigated for the same size range, i.e. $<38 \mu \mathrm{m}$ particle diameter. Biases in XRD results can be related to the presence of partly amorphous sheet silicates with poor crystallization (Leinen et al., 1994; Formenti et al., 2011; Kandler et al., 2009; Engelbrecht et al., 2016) and a subsequent overestimation of the quartz fractions. Knowing the answers to such questions would be necessary for properly using the data to constrain or evaluate simulations with dust models. Similarly, the individual particle analysis by CCSEM provides an overestimation of the clay fraction which can be attributed to surface coatings on the quartz and its underestimation (Engelbrecht et al., 2009a, b, 2016). What is of importance when considering the application of these results in models, health studies and remote sensing is not only the mineralogical composition of the dust but also their mineralogical interrelationships such as mineral clusters, mineral coatings and intergrowths.

From satellite images we identified four Red Sea coastal areas from which dust was frequently emitted (Jiang et al., 2009; Kalenderski et al., 2013). The 13 soil grab samples were collected from these areas for analysis and their mineralogy, chemical composition and particle size distributions were studied. We found that the Red Sea coastal samples collected in this study contain major components of 
quartz and feldspar (plagioclase, orthoclase), as well as lesser but variable amounts of amphibole (hornblende), pyroxene (aegirine-augite), carbonate (calcite, dolomite), clays (illite, palygorskite, kaolinite, smectite), and micas (muscovite, biotite), with traces of gypsum, halite, chlorite, epidote and oxides. The range of identified minerals is ascribed to the variety of igneous and metamorphic provenance rocks along the escarpment to the east of the Red Sea coastal plain (Edgell, 2006). Similarly high fractions of quartz and feldspars were reported for Kuwait (Engelbrecht et al., 2009b) and to a lesser extent for Tallil, Tikrīt and At Tàjī in Iraq. The samples from the Red Sea coastal region of Saudi Arabia differ substantially from those from Afghanistan, Qatar, the UAE, Iraq and Kuwait because they contain substantially less calcite. They also contain much less dolomite than the sample from Al Asad in Iraq. These deviations in composition could be ascribed to differences in provenance and geology. The coastal plain is bounded by the Red Sea in the west, with the mountains of Midyan, Ash Shifa and Asir forming an escarpment to the east and the provenance for water-borne sediments to the wadis along the coastal plain. Since the igneous and metamorphic source rocks are composed of a wide range of minerals including quartz, feldspars, amphiboles, pyroxenes and micas, it can be assumed that the partially weathered sediments transported to the coastal plain during flash floods will contain similar minerals, which can in turn be suspended as mineral dust. In contrast, the samples collected in Kuwait, Iraq and Afghanistan are from extensive flat-lying areas and contain minerals such as quartz, calcite and dolomite from local sedimentary rocks.

Djibouti lies along the Great Rift Valley along the west coast of the Gulf of Aden and close to igneous and metamorphic rock formations of the Nubian Plate, separated from the petrographically similar Arabian Plate by the Red Sea. Both regions contain rock formations with substantial amounts of pyroxene, amphibole and plagioclase. This at least in part explains the similarity of soils and dust at Djibouti to those along the coastal plain of Saudi Arabia. The mineralogical content of the soils was found to be closely related to the regional geology.

Particle size analysis on the sampled soils showed them to contain too much sand and too little silt to be considered major globally important sources of airborne dust, compared to renowned global sources such as the Bodélé Depression and silt-covered regions of the northwest USA (Engelbrecht et al., 2012; Engelbrecht and Moosmüller, 2014). The low silt content in the investigated samples suggests that the dust plume generated from the Red Sea coastal region is enriched by the coarse dust fraction that deposits quickly. As seen from atmospheric observations, the coastal region is the origin of frequent dust plumes over the Red Sea, probably due to frequent strong wind gusts. This mostly coarse dust could not be transported the vast distances to the Red Sea and directly deposited there, thus affecting marine life. Our analysis revealed that the samples contain compounds of nitrogen, phosphorus and iron, which are essential nutrients to marine life (Guerzoni et al., 1997; Migon et al., 2001). The integration of analytical information on dust mineralogy and mineralogical interrelationships, chemistry, and physical properties of soils provides a better understanding of their potential impact on the communities living along the Red Sea (Edgell, 2006; UCAR/NCAR, 2003; Washington et al., 2003). The results from this study can also provide improvements to the input of climate forecasting and dust emission models. The 13 chemical source profiles of this study will complement those of soil samples in source attribution studies collected in other regions of the Middle East (Engelbrecht et al., 2009b).

Analytical methods developed in this phase of the dust program will be applied for analysis of dust samples deposited from the atmosphere for aerosol characterization studies in the Red Sea coastal region. These will allow for further assessment of the impact of elevated dust concentrations on regional climate, marine ecology, air quality and health.

\section{Data availability}

The mineralogical and chemical data from this study are available upon request from Georgiy Stenchikov (georgiy.stenchikov@kaust.edu.sa). 


\section{Appendix A}

Table A1. Major, minor and trace element concentrations (Conc.) and analytical uncertainties (Unc.) of grab samples S1 to S3 collected near Al Nasaif and S4 to S6 collected near Ar Rāyis, all along the Red Sea coastal region. Also tabulated are elemental mass ratios, statistics of the individual particle sizes and morphology as measured by CCSEM.

\begin{tabular}{|c|c|c|c|c|c|c|c|c|c|c|c|c|c|c|c|c|c|c|}
\hline \multirow[t]{2}{*}{ Sample no. } & \multicolumn{3}{|c|}{$\mathrm{S} 1$} & \multicolumn{3}{|c|}{$\mathrm{S} 2$} & \multicolumn{3}{|c|}{ S3 } & \multicolumn{3}{|c|}{$\mathrm{S} 4$} & \multicolumn{3}{|c|}{ S5 } & \multicolumn{3}{|c|}{ S6 } \\
\hline & Conc. & & Unc. & Conc. & & Unc. & Conc. & & Unc. & Conc. & & Unc. & Conc. & & Unc. & Conc. & & Unc. \\
\hline \multicolumn{19}{|c|}{ Major and minor elements as oxides (\%) } \\
\hline $\mathrm{SiO}_{2}$ & 63.795 & \pm & 3.190 & 70.302 & \pm & 3.515 & 74.337 & \pm & 3.717 & 65.436 & \pm & 3.272 & 74.872 & \pm & 3.744 & 77.668 & \pm & 3.883 \\
\hline $\mathrm{TiO}_{2}$ & 1.577 & \pm & 0.079 & 1.700 & \pm & 0.085 & 2.536 & \pm & 0.127 & 1.300 & \pm & 0.065 & 1.237 & \pm & 0.062 & 1.511 & \pm & 0.076 \\
\hline $\mathrm{Al}_{2} \mathrm{O}_{3}$ & 6.768 & \pm & 0.338 & 5.195 & \pm & 0.260 & 4.664 & \pm & 0.233 & 4.367 & \pm & 0.218 & 7.260 & \pm & 0.363 & 4.710 & \pm & 0.236 \\
\hline $\mathrm{Fe}_{2} \mathrm{O}_{3}$ & 8.195 & \pm & 0.410 & 7.777 & \pm & 0.389 & 10.497 & \pm & 0.525 & 6.535 & \pm & 0.327 & 6.936 & \pm & 0.347 & 7.584 & \pm & 0.379 \\
\hline $\mathrm{MnO}$ & 0.112 & \pm & 0.006 & 0.119 & \pm & 0.006 & 0.135 & \pm & 0.007 & 0.109 & \pm & 0.005 & 0.123 & \pm & 0.006 & 0.144 & \pm & 0.007 \\
\hline $\mathrm{MgO}$ & 2.903 & \pm & 0.145 & 3.137 & \pm & 0.157 & 2.478 & \pm & 0.124 & 2.741 & \pm & 0.137 & 2.824 & \pm & 0.141 & 2.767 & \pm & 0.138 \\
\hline $\mathrm{CaO}$ & 1.723 & \pm & 0.086 & 1.200 & \pm & 0.060 & 0.895 & \pm & 0.045 & 0.900 & \pm & 0.045 & 1.249 & \pm & 0.062 & 0.909 & \pm & 0.045 \\
\hline $\mathrm{Na}_{2} \mathrm{O}$ & 1.695 & \pm & 0.085 & 1.577 & \pm & 0.079 & 1.657 & \pm & 0.083 & 1.494 & \pm & 0.075 & 1.248 & \pm & 0.062 & 1.659 & \pm & 0.083 \\
\hline $\mathrm{K}_{2} \mathrm{O}$ & 1.473 & \pm & 0.074 & 1.372 & \pm & 0.069 & 1.269 & \pm & 0.063 & 1.198 & \pm & 0.060 & 1.579 & \pm & 0.079 & 1.484 & \pm & 0.074 \\
\hline $\mathrm{P}_{2} \mathrm{O}_{5}$ & 0.406 & \pm & 0.048 & 0.353 & \pm & 0.047 & 0.400 & \pm & 0.048 & 0.364 & \pm & 0.048 & 0.291 & \pm & 0.046 & 0.403 & \pm & 0.048 \\
\hline Total & \multicolumn{3}{|c|}{88.649} & \multicolumn{3}{|c|}{92.734} & \multicolumn{3}{|c|}{98.867} & \multicolumn{3}{|c|}{84.444} & \multicolumn{3}{|c|}{97.620} & \multicolumn{3}{|c|}{98.838} \\
\hline \multicolumn{19}{|c|}{ Trace elements (ppm) } \\
\hline $\mathrm{Li}$ & 17 & \pm & 1 & 21 & \pm & 1 & 15 & \pm & 1 & 19 & \pm & 1 & 24 & \pm & 1 & 22 & \pm & 1 \\
\hline $\mathrm{V}$ & 183 & \pm & 9 & 182 & \pm & 9 & 242 & \pm & 12 & 161 & \pm & 8 & 166 & \pm & 8 & 191 & \pm & 10 \\
\hline $\mathrm{Cr}$ & 114 & \pm & 6 & 103 & \pm & 5 & 150 & \pm & 8 & 83 & \pm & 4 & 91 & \pm & 5 & 98 & \pm & 5 \\
\hline $\mathrm{Co}$ & 30 & \pm & 1 & 27 & \pm & 1 & 26 & \pm & 1 & 29 & \pm & 1 & 28 & \pm & 1 & 29 & \pm & 1 \\
\hline $\mathrm{Ni}$ & 55 & \pm & 3 & 52 & \pm & 3 & 46 & \pm & 2 & 45 & \pm & 2 & 48 & \pm & 2 & 50 & \pm & 3 \\
\hline $\mathrm{Cu}$ & 29 & \pm & 1 & 33 & \pm & 2 & 24 & \pm & 1 & 42 & \pm & 2 & 40 & \pm & 2 & 42 & \pm & 2 \\
\hline $\mathrm{Zn}$ & 39 & \pm & 2 & 39 & \pm & 2 & 40 & \pm & 2 & 39 & \pm & 2 & 47 & \pm & 2 & 90 & \pm & 5 \\
\hline $\mathrm{Sr}$ & 294 & \pm & 16 & 333 & \pm & 18 & 358 & \pm & 19 & 288 & \pm & 15 & 285 & \pm & 15 & 306 & \pm & 16 \\
\hline $\mathrm{Ba}$ & 318 & \pm & 16 & 426 & \pm & 21 & 342 & \pm & 17 & 408 & \pm & 20 & 502 & \pm & 25 & 610 & \pm & 30 \\
\hline \multicolumn{19}{|c|}{ Water-soluble ions (\%) } \\
\hline $\mathrm{Mg}^{2+}$ & 0.046 & \pm & 0.001 & 0.038 & \pm & 0.001 & 0.027 & \pm & 0.001 & 0.036 & \pm & 0.001 & 0.044 & \pm & 0.001 & 0.143 & \pm & 0.004 \\
\hline $\mathrm{Ca}^{2+}$ & 0.171 & \pm & 0.022 & 0.106 & \pm & 0.014 & 0.071 & \pm & 0.009 & 0.107 & \pm & 0.014 & 0.162 & \pm & 0.021 & 0.455 & \pm & 0.058 \\
\hline $\mathrm{Na}^{+}$ & 0.024 & \pm & 0.001 & 0.005 & \pm & 0.001 & 0.007 & \pm & 0.001 & 0.005 & \pm & 0.001 & 0.008 & \pm & 0.001 & 0.025 & \pm & 0.003 \\
\hline $\mathrm{K}^{+}$ & 0.020 & \pm & 0.002 & 0.010 & \pm & 0.001 & 0.008 & \pm & 0.001 & 0.011 & \pm & 0.001 & 0.025 & \pm & 0.002 & 0.037 & \pm & 0.004 \\
\hline $\mathrm{Cl}^{-}$ & 0.092 & \pm & 0.004 & 0.000 & \pm & 0.001 & 0.000 & \pm & 0.001 & 0.000 & \pm & 0.001 & 0.040 & \pm & 0.002 & 0.222 & \pm & 0.010 \\
\hline $\mathrm{SO}_{4}^{2-}$ & 0.078 & \pm & 0.001 & 0.031 & \pm & 0.001 & 0.017 & \pm & 0.001 & 0.126 & \pm & 0.002 & 0.131 & \pm & 0.002 & 0.466 & \pm & 0.007 \\
\hline $\mathrm{PO}_{4}^{\frac{4}{3}-}$ & 0.002 & \pm & 0.001 & 0.002 & \pm & 0.001 & 0.000 & \pm & 0.001 & 0.000 & \pm & 0.001 & 0.002 & \pm & 0.001 & 0.006 & \pm & 0.004 \\
\hline $\mathrm{NO}_{3}^{-}$ & 0.018 & \pm & 0.002 & 0.006 & \pm & 0.001 & 0.011 & \pm & 0.001 & 0.016 & \pm & 0.002 & 0.019 & \pm & 0.002 & 0.076 & \pm & 0.007 \\
\hline \multicolumn{19}{|l|}{ Mass ratios } \\
\hline $\mathrm{Si} / \mathrm{Al}$ & \multicolumn{3}{|c|}{8.321} & & 1.946 & & & 14.071 & & & 3.227 & & & 9.105 & & & 14.558 & \\
\hline $\mathrm{Ca} / \mathrm{Al}$ & & 0.344 & & & 0.312 & & & 0.259 & & & 0.279 & & & 0.233 & & & 0.261 & \\
\hline $\mathrm{Fe} / \mathrm{Al}$ & & 1.600 & & & 1.978 & & & 2.974 & & & 1.977 & & & 1.262 & & & 2.128 & \\
\hline Particle diameter fr & m CCSEI & M mea & suremer & approx. 2 & $000 \mathrm{pa}$ & (rticles) & & & & & & & & & & & & \\
\hline Geom. mean $(\mu \mathrm{m})$ & & 2.81 & & & 2.12 & & & 3.50 & & & 2.24 & & & 2.53 & & & 2.35 & \\
\hline Arith. mean $(\mu \mathrm{m})$ & & 3.66 & & & 2.72 & & & 6.75 & & & 3.25 & & & 3.29 & & & 3.00 & \\
\hline Skewness & & 4.57 & & & 4.32 & & & 2.34 & & & 5.04 & & & 5.44 & & & 5.51 & \\
\hline Kurtosis & & 28.85 & & & 25.20 & & & 4.63 & & & 29.43 & & & 40.11 & & & 44.00 & \\
\hline Mean aspect ratio & & 1.41 & & & 1.42 & & & 1.48 & & & 1.45 & & & 1.41 & & & 1.41 & \\
\hline
\end{tabular}


Table A2. Major, minor and trace element concentrations (Conc.) and analytical uncertainties (Unc.) of grab samples S7 to S9 collected near Yanbu and S10 to S13 near Mecca, all along the Red Sea coastal region. Also tabulated are elemental mass ratios, statistics of the individual particle size and morphology as measured by CCSEM.

\begin{tabular}{|c|c|c|c|c|c|c|c|c|c|c|c|c|c|c|c|c|c|c|c|c|c|}
\hline \multirow[t]{2}{*}{ Sample no. } & \multicolumn{3}{|c|}{ S7 } & \multicolumn{3}{|c|}{ S8 } & \multicolumn{3}{|c|}{ S9 } & \multicolumn{3}{|c|}{ S10 } & \multicolumn{3}{|c|}{ S11 } & \multicolumn{3}{|c|}{ S12 } & \multicolumn{3}{|c|}{ S13 } \\
\hline & Conc. & & Unc. & Conc. & & Unc. & Conc. & & Unc. & Conc. & & Unc. & Conc. & & Unc. & Conc. & & Unc. & Conc. & & Unc. \\
\hline \multicolumn{22}{|c|}{ Major and minor elements as oxides (\%) } \\
\hline $\mathrm{SiO}_{2}$ & 71.041 & \pm & 3.552 & 77.76 & \pm & 3.888 & 62.997 & \pm & 3.150 & 78.006 & \pm & 3.900 & 64.44 & \pm & 3.222 & 71.091 & \pm & 3.555 & 65.173 & \pm & 3.259 \\
\hline $\mathrm{TiO}_{2}$ & 2.246 & \pm & 0.112 & 1.22 & \pm & 0.061 & 2.401 & \pm & 0.120 & 1.793 & \pm & 0.090 & 2.09 & \pm & 0.104 & 1.499 & \pm & 0.075 & 1.786 & \pm & 0.089 \\
\hline $\mathrm{Al}_{2} \mathrm{O}_{3}$ & 4.080 & \pm & 0.204 & 4.33 & \pm & 0.217 & 4.351 & \pm & 0.218 & 3.697 & \pm & 0.185 & 3.70 & \pm & 0.185 & 4.516 & \pm & 0.226 & 4.198 & \pm & 0.210 \\
\hline $\mathrm{Fe}_{2} \mathrm{O}_{3}$ & 9.563 & \pm & 0.478 & 7.43 & \pm & 0.371 & 11.027 & \pm & 0.551 & 7.997 & \pm & 0.400 & 10.07 & \pm & 0.504 & 8.604 & \pm & 0.430 & 9.936 & \pm & 0.497 \\
\hline $\mathrm{MnO}$ & 0.121 & \pm & 0.006 & 0.10 & \pm & 0.005 & 0.156 & \pm & 0.008 & 0.126 & \pm & 0.006 & 0.13 & \pm & 0.007 & 0.115 & \pm & 0.006 & 0.117 & \pm & 0.006 \\
\hline $\mathrm{MgO}$ & 2.255 & \pm & 0.113 & 2.53 & \pm & 0.127 & 2.76 & \pm & 0.138 & 2.549 & \pm & 0.127 & 2.62 & \pm & 0.131 & 2.556 & \pm & 0.128 & 2.345 & \pm & 0.117 \\
\hline $\mathrm{CaO}$ & 1.109 & \pm & 0.055 & 1.02 & \pm & 0.051 & 1.071 & \pm & 0.054 & 1.064 & \pm & 0.053 & 1.55 & \pm & 0.077 & 1.547 & \pm & 0.077 & 1.586 & \pm & 0.079 \\
\hline $\mathrm{Na}_{2} \mathrm{O}$ & 2.015 & \pm & 0.101 & 1.92 & \pm & 0.096 & 1.638 & \pm & 0.082 & 1.485 & \pm & 0.074 & 1.31 & \pm & 0.066 & 1.248 & \pm & 0.062 & 1.255 & \pm & 0.063 \\
\hline $\mathrm{K}_{2} \mathrm{O}$ & 1.495 & \pm & 0.075 & 1.49 & \pm & 0.074 & 1.335 & \pm & 0.067 & 1.059 & \pm & 0.053 & 0.96 & \pm & 0.048 & 0.942 & \pm & 0.047 & 1.040 & \pm & 0.052 \\
\hline $\mathrm{P}_{2} \mathrm{O}_{5}$ & 0.467 & \pm & 0.050 & 0.452 & \pm & 0.049 & 0.461 & \pm & 0.050 & 0.385 & \pm & 0.048 & 0.446 & \pm & 0.049 & 0.384 & \pm & 0.048 & 0.384 & \pm & 0.048 \\
\hline Total & \multicolumn{3}{|c|}{94.392} & \multicolumn{3}{|c|}{98.250} & \multicolumn{3}{|c|}{88.192} & \multicolumn{3}{|c|}{98.160} & \multicolumn{3}{|c|}{87.326} & \multicolumn{3}{|c|}{92.503} & \multicolumn{3}{|c|}{87.819} \\
\hline \multicolumn{22}{|c|}{ Trace elements (ppm) } \\
\hline $\mathrm{Li}$ & 16 & \pm & 1 & 17 & \pm & 1 & 19 & \pm & 1 & 14 & \pm & 1 & 14 & \pm & 1 & 13 & \pm & 1 & 12 & \pm & 1 \\
\hline $\mathrm{V}$ & 215 & \pm & 11 & 157 & \pm & 8 & 257 & \pm & 13 & 216 & \pm & 11 & 283 & \pm & 14 & 229 & \pm & 11 & 284 & \pm & 14 \\
\hline $\mathrm{Cr}$ & 129 & \pm & 6 & 94 & \pm & 5 & 167 & \pm & 8 & 142 & \pm & 7 & 177 & \pm & 9 & 149 & \pm & 7 & 171 & \pm & 9 \\
\hline Co & 26 & \pm & 1 & 25 & \pm & 1 & 29 & \pm & 1 & 31 & \pm & 2 & 35 & \pm & 2 & 36 & \pm & 2 & 32 & \pm & 2 \\
\hline $\mathrm{Ni}$ & 47 & \pm & 2 & 46 & \pm & 2 & 53 & \pm & 3 & 58 & \pm & 3 & 65 & \pm & 3 & 61 & \pm & 3 & 59 & \pm & 3 \\
\hline $\mathrm{Cu}$ & 21 & \pm & 1 & 22 & \pm & 1 & 24 & \pm & 1 & 52 & \pm & 3 & 55 & \pm & 3 & 58 & \pm & 3 & 47 & \pm & 2 \\
\hline $\mathrm{Zn}$ & 41 & \pm & 2 & 38 & \pm & 2 & 44 & \pm & 2 & 41 & \pm & 2 & 42 & \pm & 2 & 42 & \pm & 2 & 39 & \pm & 2 \\
\hline $\mathrm{Sr}$ & 233 & \pm & 13 & 180 & \pm & 11 & 381 & \pm & 20 & 281 & \pm & 15 & 267 & \pm & 14 & 259 & \pm & 14 & 199 & \pm & 11 \\
\hline $\mathrm{Ba}$ & 306 & \pm & 15 & 302 & \pm & 15 & 404 & \pm & 20 & 430 & \pm & 21 & 409 & \pm & 20 & 407 & \pm & 20 & 323 & \pm & 16 \\
\hline Water-soluble ions & & & & & & & & & & & & & & & & & & & & & \\
\hline $\mathrm{Mg}^{2+}$ & 0.024 & \pm & 0.001 & 0.024 & \pm & 0.001 & 0.026 & \pm & 0.001 & 0.025 & \pm & 0.001 & 0.025 & \pm & 0.001 & 0.025 & \pm & 0.001 & 0.028 & \pm & 0.001 \\
\hline $\mathrm{Ca}^{2+}$ & 0.139 & \pm & 0.018 & 0.138 & \pm & 0.018 & 0.126 & \pm & 0.016 & 0.105 & \pm & 0.018 & 0.061 & \pm & 0.008 & 0.081 & \pm & 0.010 & 0.073 & \pm & 0.009 \\
\hline $\mathrm{Na}^{+}$ & 0.019 & \pm & 0.001 & 0.012 & \pm & 0.000 & 0.009 & \pm & 0.001 & 0.008 & \pm & 0.000 & 0.009 & \pm & 0.001 & 0.009 & \pm & 0.001 & 0.019 & \pm & 0.001 \\
\hline $\mathrm{K}^{+}$ & 0.016 & \pm & 0.001 & 0.014 & \pm & 0.001 & 0.016 & \pm & 0.001 & 0.016 & \pm & 0.001 & 0.012 & \pm & 0.001 & 0.016 & \pm & 0.001 & 0.018 & \pm & 0.001 \\
\hline $\mathrm{Cl}^{-}$ & 0.046 & \pm & 0.002 & 0.037 & \pm & 0.002 & 0.026 & \pm & 0.001 & 0.000 & \pm & 0.002 & 0.000 & \pm & 0.001 & 0.000 & \pm & 0.001 & 0.000 & \pm & 0.001 \\
\hline $\mathrm{SO}_{4}^{2-}$ & 0.088 & \pm & 0.001 & 0.056 & \pm & 0.001 & 0.038 & \pm & 0.001 & 0.091 & \pm & 0.001 & 0.049 & \pm & 0.001 & 0.070 & \pm & 0.001 & 0.063 & \pm & 0.001 \\
\hline $\mathrm{PO}_{4}^{3-}$ & 0.002 & \pm & 0.001 & 0.001 & \pm & 0.001 & 0.000 & \pm & 0.001 & 0.001 & \pm & 0.001 & 0.001 & \pm & 0.001 & 0.001 & \pm & 0.001 & 0.002 & \pm & 0.001 \\
\hline $\mathrm{NO}_{3}^{-}$ & 0.014 & \pm & 0.001 & 0.009 & \pm & 0.001 & 0.005 & \pm & 0.001 & 0.024 & \pm & 0.001 & 0.012 & \pm & 0.001 & 0.017 & \pm & 0.002 & 0.016 & \pm & 0.001 \\
\hline Mass ratios & & & & & & & & & & & & & & & & & & & & & \\
\hline $\mathrm{Si} / \mathrm{Al}$ & & 15.370 & & & 15.846 & & & 12.782 & & & 18.628 & & & 15.368 & & & 13.896 & & & 13.705 & \\
\hline $\mathrm{Ca} / \mathrm{Al}$ & & 0.367 & & & 0.318 & & & 0.333 & & & 0.389 & & & 0.564 & & & 0.463 & & & 0.511 & \\
\hline $\mathrm{Fe} / \mathrm{Al}$ & & 3.097 & & & 2.266 & & & 3.349 & & & 2.858 & & & 3.595 & & & 2.517 & & & 3.127 & \\
\hline Particle diameter fro & $\mathrm{m} \mathrm{CCSE}$ & M mea & sureme & prox. 2 & $2000 \mathrm{p}$ & articles & & & & & & & & & & & & & & & \\
\hline Geom. mean $(\mu \mathrm{m})$ & & 2.68 & & & 2.43 & & & 2.55 & & & 2.21 & & & 2.52 & & & 2.63 & & & 2.82 & \\
\hline Arith. mean $(\mu \mathrm{m})$ & & 4.50 & & & 4.18 & & & 4.47 & & & 3.67 & & & 4.05 & & & 4.17 & & & 4.94 & \\
\hline Skewness & & 3.61 & & & 3.83 & & & 3.63 & & & 4.35 & & & 4.21 & & & 3.93 & & & 3.34 & \\
\hline Kurtosis & & 13.38 & & & 14.87 & & & 13.14 & & & 19.06 & & & 18.56 & & & 16.74 & & & 11.20 & \\
\hline Mean aspect ratio & & 1.40 & & & 1.46 & & & 1.43 & & & 1.42 & & & 1.41 & & & 1.43 & & & 1.41 & \\
\hline
\end{tabular}




\section{The Supplement related to this article is available online at doi:10.5194/acp-16-11991-2016-supplement.}

Author contributions. Georgiy Stenchikov formulated the problem, designed the research project and supported experimental activities; Johann P. Engelbrecht advised on aerosol analysis and instrumentation; Weichun Tao defined the dust source areas using satellite observations; P. Jish Prakash conducted measurements, analyzed and combined results; Tahir Yapici and Bashir Warsama helped with instrumentation in the Kaust Core Lab. P. Jish Prakash, Johann P. Engelbrecht and Georgiy Stenchikov wrote different parts of the paper.

Acknowledgements. This research, including the chemical and mineralogical analysis, is supported by internal funding from the King Abdullah University of Science and Technology (KAUST). For chemical analyses, this research used the resources of the KAUST core lab. We acknowledge the contribution from the collaborating laboratories of the RJ Lee Group and Desert Research Institute.

Edited by: P. Formenti

Reviewed by: K. Kandler and one anonymous referee

\section{References}

Aba-Husayn, M. M., Dixon, J. B., and Lee, S. Y.: Mineralogy of Saudi Arabian Soils: Southwestern Region, Soil Sci. Soc. Am. J., 44, 643-649, doi:10.2136/sssaj1980.03615995004400030043x, 1980.

Acosta, F., Ngugi, D. K., and Stingl, U.: Diversity of picoeukaryotes at an oligotrophic site off the Northeastern Red Sea Coast, Aquat. Biosyst., 9, 16, doi:10.1186/2046-9063-9-16, 2013.

Al-Farraj, A. S.: The mineralogy of clay fractions in the soils of the southern region of Jazan, Saudi Arabia, J. Agron., 7, 115-126, 2008.

Bennett, C. M., McKendry, I. G., Kelly, S., Denike, K., and Koch, T.: Impact of the 1998 Gobi dust event on hospital admissions in the Lower Fraser Valley, British Columbia, Sci. Total Environ., 366, 918-925, doi:10.1016/j.scitotenv.2005.12.025, 2006.

Bennion, P., Hubbard, R., O'Hara, S., Wiggs, G., Wegerdt, J., Lewis, S., Small, I., van der Meer, J., and Upshur, R.: The impact of airborne dust on respiratory health in children living in the Aral Sea region, Int. J. Epidemiol., 36, 1103-1110, doi:10.1093/ije/dym195, 2007.

Brindley, H., Osipov, S., Bantges, R., Smirnov, A., Banks, J., Levy, R., Jish Prakash, P., and Stenchikov, G.: An assessment of the quality of aerosol retrievals over the Red Sea and evaluation of the climatological cloud-free dust direct radiative effect in the region, J. Geophys. Res.-Atmos., 120, 2015JD023282, doi:10.1002/2015JD023282, 2015.

Bristow, C. S., Hudson-Edwards, K. A., and Chappell, A.: Fertilizing the Amazon and equatorial Atlantic with West African dust, Geophys. Res. Lett., 37, L14807, doi:10.1029/2010GL043486, 2010.
Buseck, P. R., Jacob, D. J., Pósfai, M., Li, J., and Anderson, J. R.: Minerals in the air: An environmental perspective, International Geology Review, Symposium, Stanford, California, 1999.

Caquineau, S., Magonthier, M.-C., Gaudichet, A., and Gomes, L.: An improved procedure for the X-ray diffraction analysis of lowmass atmospheric dust samples, Eur. J. Mineral., 9, 157-166, 1997.

Chung, F. H.: Quantitative interpretation of X-ray diffraction patterns of mixtures. I. Matrix-flushing method for quantitative multicomponent analysis, J. Appl. Crystallogr., 7, 519-525, doi:10.1107/S0021889874010375, 1974.

De Longueville, F., Hountondji, Y. C., Henry, S., and Ozer, P.: What do we know about effects of desert dust on air quality and human health in West Africa compared to other regions?, Sci. Total Environ., 409, 1-8, 2010.

Edgell, H. S.: Arabian Deserts, Nature, Origin and Evolution, Springer, Dordrecht, the Netherlands, 592 pp., 2006.

Engelbrecht, J. P. and Moosmüller, H.: Mobile Aerosol Monitoring System for Department of Defense - Continuous Aerosol and Aerosol Optics Measurement in Theater, U.S. Army Medical Research and Materiel Command, Fort Detrick, Maryland Report W81XWH-11-2-0220, 1-229, 2014.

Engelbrecht, J. P., McDonald, E. V., Gillies, J. A., Jayanty, R. K. M., Casuccio, G., and Gertler, A. W.: Characterizing mineral dusts and other aerosols from the Middle East - Part 1: Ambient sampling, Inhalation Toxicol., 21, 297-326, 2009a.

Engelbrecht, J. P., McDonald, E. V., Gillies, J. A., Jayanty, R. K. M., Casuccio, G., and Gertler, A. W.: Characterizing mineral dusts and other aerosols from the Middle East - Part 2: Grab samples and re-suspensions, Inhalation Toxicol., 21, 327-336, 2009b.

Engelbrecht, J. P., Gillies, J. A., Etyemezian, V., Kuhns, H., Baker, S. E., Zhu, D., Nikolich, G., and Kohl, S. D.: Controls on mineral dust emissions at four arid locations in the western USA, Aeolian Res., 6, 41-54, 2012.

Engelbrecht, J. P., Moosmüller, H., Pincock, S., Jayanty, R. K. M., Lersch, T., and Casuccio, G.: Technical note: Mineralogical, chemical, morphological, and optical interrelationships of mineral dust re-suspensions, Atmos. Chem. Phys., 16, 10809-10830, doi:10.5194/acp-16-10809-2016, 2016.

Esteve, V., Rius, J., Ochando, L. E., and Amigó, J. M.: Quantitative X-ray diffraction phase analysis of coarse airborne particulate collected by cascade impactor sampling, Atmos. Environ., 31, 3963-3967, doi:10.1016/S1352-2310(97)00257-4, 1997.

Formenti, P., Rajot, J. L., Desboeufs, K., Saïd, F., Grand, N., Chevaillier, S., and Schmechtig, C.: Airborne observations of mineral dust over western Africa in the summer Monsoon season: spatial and vertical variability of physico-chemical and optical properties, Atmos. Chem. Phys., 11, 6387-6410, doi:10.5194/acp-11-6387-2011, 2011.

Fryrear, D. W.: Long-term effect of erosion and cropping on soil productivity, Spec. Pap.-Geol. Soc. Am., 186, 253-260, doi:10.1130/SPE186-p253, 1981.

Gee, G. W. and Or, D.: Particle-size analysis, in: Methods of Soil Analysis: Part 4 - Physical Methods, No. 5, edited by: Dane, J. H. and Topp, G. C., Soil Science Society of America, Madison, WI, 255-293, 2002.

Gillette, D. A. and Walker, T. R.: Characteristics of airborne particles produced by wind erosion of sandy soil, High Plains of West Texas, Soil Sci., 123, 97-110, 1977. 
Goldstein, J., Newbury, D., Joy, D., Lyman, C., Echlin, P., Lifshin, E., Sawyer, L., and Michael, J.: Scanning Electron Microscopy and X-Ray Microanalysis, 3rd Edn., Springer, 689 pp., 2003.

Goudie, A. S. and Middleton, N. J.: Desert Dust in the Global System, Springer, Germany, 287 pp., 2006.

Grainger, D.: The Geological Evolution of Saudi Arabia, a Voyage through Space and Time Saudi Geological Survey, Jeddah, Saudi Arabia, ISBNS 9781905755073, 264 pp., 2007.

Greely, R. and Iversen, J. D.: Wind as a geological process on Earth, Mars, and Venus, Cambridge University Press, Cambridge, 333 pp., 1985.

Grell, G. A., Peckham, S. E., Schmitz, R., McKeen, S. A., Frost, G., Skamarock, W. C., and Eder, B.: Fully coupled "online" chemistry within the WRF model, Atmos. Environ., 39, 6957-6975, doi:10.1016/j.atmosenv.2005.04.027, 2005.

Guerzoni, S., Molinaroli, E., and Chester, R.: Saharan dust inputs to the western Mediterranean Sea: depositional patterns, geochemistry and sedimentological implications, Deep-Sea Res. Pt. II, 44, 631-654, 1997

Hagen, L. J. and Woodruff, N. P.: Air pollution from dust storms in the Great Plains, Atmos. Environ., 7, 323-332, 1973.

Haywood, J. and Boucher, O.: Estimates of the direct and indirect radiative forcing due to tropospheric aerosols: A review, Rev. Geophys., 38, 513-543, doi:10.1029/1999RG000078, 2000.

Hsu, N. C., Tsay, S. C., King, M. D., and Herman, J. R.: Aerosol properties over bright-reflecting source regions, IEEE T. Geosci., 42, 557-569, 2004.

Huang, J., Minnis, P., Lin, B., Wang, T., Yi, Y., Hu, Y., SunMack, S., and Ayers, K.: Possible influences of Asian dust aerosols on cloud properties and radiative forcing observed from MODIS and CERES, Geophys. Res. Lett., 33, L06824, doi:10.1029/2005GL024724, 2006.

Huang, J., Wang, T., Wang, W., Li, Z., and Yan, H.: Climate effects of dust aerosols over East Asian arid and semiarid regions, J. Geophys. Res.-Atmos., 119, 11398-11416, doi:10.1002/2014JD021796, 2014.

Jiang, H., Farrar, J. T., Beardsley, R. C., Chen, R., and Chen, C.: Zonal surface wind jets across the Red Sea due to mountain gap forcing along both sides of the Red Sea, Geophys. Res. Lett., 36, L19605, doi:10.1029/2009GL040008, 2009.

Jickells, T. D., An, Z. S., Andersen, K. K., Baker, A. R., Bergametti, G., Brooks, N., Cao, J. J., Boyd, P. W., Duce, R. A., Hunter, K. A., Kawahata, H., Kubilay, N., laRoche, J., Liss, P. S., Mahowald, N., Prospero, J. M., Ridgwell, A. J., Tegen, I., and Torres, R.: Global iron connections between desert dust, ocean biogeochemistry, and climate, Science, 308, 67-71, 2005.

Jish Prakash, P., Stenchikov, G., Kalenderski, S., Osipov, S., and Bangalath, H.: The impact of dust storms on the Arabian Peninsula and the Red Sea, Atmos. Chem. Phys., 15, 199-222, doi:10.5194/acp-15-199-2015, 2015.

Kalenderski, S., Stenchikov, G., and Zhao, C.: Modeling a typical winter-time dust event over the Arabian Peninsula and the Red Sea, Atmos. Chem. Phys., 13, 1999-2014, doi:10.5194/acp-131999-2013, 2013.

Kandler, K., Schütz, L., Deutscher, C., Ebert, M., Hofmann, H., Jäckel, S., Jaenicke, R., Knippertz, P., Lieke, K., Massling, A., Petzold, A., Schladitz, A., Weinzierl, B., Wiedensohler, A., Zorn, S., and Weinbruch, S.: Size distribution, mass concentration, chemical and mineralogical composition and derived optical pa- rameters of the boundary layer aerosol at Tinfou, Morocco, during SAMUM 2006, Tellus B, 61, 32-50, 2009.

Kerr, P. F.: Optical Mineralogy, 3rd Edn., McGraw-Hill Book Company, Inc., USA, 442 pp., 1959.

Kok, J. F.: A scaling theory for the size distribution of emitted dust aerosols suggests climate models underestimate the size of the global dust cycle, P. Natl. Acad. Sci. USA, 108, 1016-1021, 2011a.

Kok, J. F.: Does the size distribution of mineral dust aerosols depend on the wind speed at emission?, Atmos. Chem. Phys., 11, 1014910156, doi:10.5194/acp-11-10149-2011, 2011 b.

Kumar, R., Barth, M. C., Pfister, G. G., Naja, M., and Brasseur, G. P.: WRF-Chem simulations of a typical pre-monsoon dust storm in northern India: influences on aerosol optical properties and radiation budget, Atmos. Chem. Phys., 14, 2431-2446, doi:10.5194/acp-14-2431-2014, 2014.

Leinen, M., Prospero, J. M., Arnold, E., and Blank, M.: Mineralogy of aeolian dust reaching the North Pacific Ocean 1. Sampling and analysis, J. Geophys. Res., 99, 21017-21023, 1994.

Mahowald, N., Engelstaedter, S., Luo, C., Sealy, A., Artaxo, P., Benitez-Nelson, C., Bonnet, S., Chen, Y., Chuang, P. Y., Cohen, D. D., Dulac, F., Herut, B., Johansen, A. M., Kubilay, N., Losno, R., Maenhaut, W., Paytan, A., Prospero, J. M., Shank, L. M., and Siefert, R. L.: Atmospheric iron deposition: Global distribution, variability and human perturbations, Ann. Rev. Mar. Sci., 1, 245278, 2009.

Marticorena, B.: Dust production mechanisms, in: Mineral Dust: A Key Player in the Earth System, edited by: Knippertz, P. and Stuut, J.-B. W., Springer Science+Business Media, Dordrecht, 93-120, 2014.

Marticorena, B. and Bergametti, G.: Modeling the atmospheric dust cycle: 1. Design of a soil-derived dust emission scheme, J. Geophys. Res.-Atmos., 100, 16415-16430, doi:10.1029/95JD00690, 1995.

Menéndez, I., Pérez-Chacón, E., Mangas, J., Tauler, E., Engelbrecht, J. P., Derbyshire, E., Cana, L., and Alonso, I.: Dust deposits on La Graciosa Island (Canary Islands, Spain): Texture, mineralogy and a case study of recent dust plume transport, Catena, 117, 133-144, 2014.

Menut, L., Pérez, C., Haustein, K., Bessagnet, B., Prigent, C., and Alfaro, S.: Impact of surface roughness and soil texture on mineral dust emission fluxes modeling, J. Geophys. Res.-Atmos., 118, 6505-6520, doi:10.1002/jgrd.50313, 2013.

Migon, C., Sandroni, V., and Béthoux, J. P.: Atmospheric input of anthropogenic phosphorus to the northwest Mediterranean under oligotrophic conditions, Mar. Environ. Res., 7, 1-14, 2001.

Moosmüller, H., Engelbrecht, J. P., Skiba, M., Frey, G., Chakrabarty, R. K., and Arnott, W. P.: Single scattering albedo of fine mineral dust aerosols controlled by iron concentration, $\mathrm{J}$. Geophys. Res., 117, D11210, doi:10.1029/2011JD016909, 2012.

Muhs, D. R., Prospero, J. M., Baddock, M. C., and Gill, T. E.: Identifying sources of aeolian mineral dust: Present and past, in: Mineral Dust, A Key Player in the Earth System, edited by: Knippertz, P. and Stuut, J.-B. W., Springer Science+Business Media, Dordrecht, 51-74, 2014.

Nickovic, S., Vukovic, A., Vujadinovic, M., Djurdjevic, V., and Pejanovic, G.: Technical Note: High-resolution mineralogical database of dust-productive soils for atmospheric dust model- 
ing, Atmos. Chem. Phys., 12, 845-855, doi:10.5194/acp-12-8452012, 2012.

Nihlen, T. and Lund, S. O.: Influence of Aeolian Dust on Soil Formation in the Aegean Area, Z. Geomorphol., 393, 341-361, 1995.

Oleson, K. W., Lawrence, D. M., Bonan, G. B., Flanner, M. G., Kluzek, E., Lawrence, P. J., Levis, S., Swenson, S. C., Thornton, P. E., Dai, A., Decker, M., Dickinson, R., Feddema, J., Heald, C. L., Hoffman, F., Lamarque, J., Mahowald, N., Niu, G., Qian, T., Randerson, J., Running, S., Sakaguchi, K., Slater, A., Stockli, R., Wang, A., Yang, Z., Zeng, X., and Zeng, X.: Technical Description of version 4.0 of the Community Land Model (CLM), NCAR Technical Note NCAR/TN-478+STR, 2010.

Osipov, S., Stenchikov, G., Brindley, H., and Banks, J.: Diurnal cycle of the dust instantaneous direct radiative forcing over the Arabian Peninsula, Atmos. Chem. Phys., 15, 9537-9553, doi:10.5194/acp-15-9537-2015, 2015.

Perlwitz, J. P., Pérez García-Pando, C., and Miller, R. L.: Predicting the mineral composition of dust aerosols - Part 2: Model evaluation and identification of key processes with observations, Atmos. Chem. Phys., 15, 11629-11652, doi:10.5194/acp15-11629-2015, 2015a.

Perlwitz, J. P., Pérez García-Pando, C., and Miller, R. L.: Predicting the mineral composition of dust aerosols - Part 1: Representing key processes, Atmos. Chem. Phys., 15, 11593-11627, doi:10.5194/acp-15-11593-2015, 2015b.

Prospero, J. M., Ginoux, P., Torres, O., Nicholson, S. E., and Gill, T. E.: Environmental characterization of global sources of atmospheric soil dust indentified with the NIMBUS 7 total ozone mapping spectrometer (TOMS) absorbing aerosol product, Rev. Geophys., 40, 1002, doi:10.1029/2000RG000095, 2002.

Roquin, C., Freyssinet, P., Zeegers, H., and Tardy, Y.: Element distribution patterns in laterites of southern Mali: Consequence for geochemical prospecting and mineral exploration, Appl. Geochem., 5, 303-315, 1990.

Rietveld, H. M.: A profile refinement method for nuclear and magnetic structures, J. Appl. Crystallogr., 2, 65-71, doi:10.1107/S0021889869006558, 1969.

Scheuvens, D. and Kandler, K.: On composition, morphology, and size distribution of airborne mineral dust, in: Mineral Dust, a Key Player in the Earth System, edited by: Knippertz, P. and Stuut, J.-B. W., Springer Science+Business Media, Dordrecht, 15-49, 2014.

Shadfan, H., Mashhady, A., Eter, A., and Hussen, A. A.: Mineral composition of selected soils in Saudi Arabia, J. Plant Nutr. Soil Sc., 147, 657-668, doi:10.1002/jpln.19841470603, 1984.

Sokolik, I. N. and Toon, O. B.: Direct radiative forcing by anthropogenic airborne mineral aerosols, Nature, 381, 681-683, 1996.

Sokolik, I. N. and Toon, O. B.: Incorporation of mineralogical composition into models of the radiative properties of mineral aerosol from UV to IR wavelengths, J. Geophys. Res.-Atmos., 104, 9423-9444, doi:10.1029/1998JD200048, 1999.
Sturges, W. T., Harrison, R. M., and Barrie, L. A.: Semi-quantitative $\mathrm{X}$-ray diffraction analysis of size fractionated atmospheric particles, Atmos. Environ., 23, 1083-1098, 1989.

Tanaka, T. Y. and Chiba, M.: A numerical study of the contributions of dust source regions to the global dust budget, Global Planet. Change, 52, 88-104, 2006.

Tegen, I. and Fung, I.: Contribution to the atmospheric mineral aerosol load from land surface modification, J. Geophys. Res., 100, 18707-18726, 1995.

Twomey, S. A., Piepgrass, M., and Wolfe, T. L.: An assessment of the impact of pollution on global cloud albedo, Tellus B, 36, 5, doi:10.3402/tellusb.v36i5.14916, 2011.

UCAR/NCAR: Forecasting Dust Storms, National Center for Atmospheric Research, Boulder, National Center for Atmospheric Research, Boulder, 1-67, 2003.

Viani, B. E., Al-Mashhady, A. S., and Dixon, J. B.: Mineralogy of Saudi Arabian Soils: Central Alluvial Basins, Soil Sci. Soc. Am. J., 47, 149-157, doi:10.2136/sssaj1983.03615995004700010030x, 1983.

Wang, W., Huang, J., Minnis, P., Hu, Y., Li, J., Huang, Z., Ayers, J. K., and Wang, T.: Dusty cloud properties and radiative forcing over dust source and downwind regions derived from ATrain data during the Pacific Dust Experiment, J. Geophys. Res.Atmos., 115, D00H35, doi:10.1029/2010JD014109, 2010.

Wang, Z., Ueda, H., and Huang, M.: A deflation module for use in modeling long-range transport of yellow sand over East Asia, J. Geophys. Res.-Atmos., 105, 26947-26959, doi:10.1029/2000JD900370, 2000.

Washington, R. and Todd, M. C.: Atmospheric controls on mineral dust emission from the Bodélé depression, Chad: The role of the low level jet, Geophys. Res. Lett., 32, L17701, doi:10.1029/2005GL023597, 2005.

Washington, R., Todd, M. C., Middleton, N. J., and Goudie, A. S.: Dust-storm source areas determined by the total ozone monitoring spectrometer and surface observations, Ann. Assoc. Am. Geogr., 93, 297-313, 2003.

Webb, N. P. and Strong, C. L.: Soil erodibility dynamics and its representation for wind erosion and dust emission models, Aeolian Res., 3, 165-179, doi:10.1016/j.aeolia.2011.03.002, 2011.

Weese, C. B. and Abraham, J. H.: Potential health implications associated with particulate matter exposure in deployed settings in Southwest Asia, Inhalation Toxicol., 21, 291-296, 2009.

Zender, C. S., Bian, H., and Newman, D.: Mineral Dust Entrainment and Deposition (DEAD) model:Description and 1990s dust climatology, J. Geophys. Res., 108, doi:10.1029/2002JD002775, 2003. 